\title{
Chemistry of snow and lake water in Antarctic region
}

\author{
Kaushar Ali*, Sunil Sonbawane, D M Chate, Devendraa Simngh, \\ P S P RAO, P D SAFAI and K B BudhaVANT \\ Indian Institute of Tropical Meteorology, Dr. Homi Bhabha Road, Pashan, Pune 411 008, India. \\ *e-mail: kaushar@tropmet.res.in
}

\begin{abstract}
Surface snow and lake water samples were collected at different locations around Indian station at Antarctica, Maitri, during December 2004-March 2005 and December 2006-March 2007. Samples were analyzed for major chemical ions. It is found that average $\mathrm{pH}$ value of snow is 6.1 . Average $\mathrm{pH}$ value of lake water with low chemical content is 6.2 and of lake water with high chemical content is 6.5. The $\mathrm{Na}^{+}$and $\mathrm{Cl}^{-}$are the most abundantly occurring ions at Antarctica. Considerable amount of $\mathrm{SO}_{4}^{2-}$ is also found in the surface snow and the lake water which is attributed to the oxidation of DMS produced by marine phytoplankton. Neutralization of acidic components of snow is mainly done by $\mathrm{NH}_{4}^{+}$and $\mathrm{Mg}^{2+}$. The $\mathrm{Mg}^{2+}, \mathrm{Ca}^{2+}$ and $\mathrm{K}^{+}$are nearly equally effective in neutralizing the acidic components in lake water. The $\mathrm{NH}_{4}^{+}$and $\mathrm{SO}_{4}^{2-}$ occur over the Antarctica region mostly in the form of $\left(\mathrm{NH}_{4}\right)_{2} \mathrm{SO}_{4}$.
\end{abstract}

\section{Introduction}

The continent of Antarctica may generally be regarded as a cold desert (Heywood 1984) with $98 \%$ of the land covered by ice even in the warmest area. The temperature of the continent seldom exceeds $0^{\circ} \mathrm{C}$. Hence, the precipitation in the continent is mostly characterized by snow-fall. Precipitating snow incorporates in it atmospheric aerosols and gases during nucleation. It coalesces with and collects the underlying aerosols during snowfall and traps them during deposition to the surface. Although dry deposition process provides a dominant sink mechanism on the Antarctic Plateau for the removal of atmospheric contaminants causing higher ionic contents in the snow pack than in precipitating snow (Gjessing 1984), scavenging process by snow predominates in the coastal Antarctica (Wolff et al 1998), the region more affected by changing sea-ice extent and cyclonic activity than the high-altitude areas (King and Turner 1997). The chemical composition of surface snow can provide significant information on atmospheric aerosols (their sources and sinks) and the air quality over the Antarctic region.

In order to interpret temporal changes of ion chemistry records from deep ice cores drilled at a single site, it is essential to understand spatial distribution of chemical components in surface deposited snow as well as the factors controlling the atmospheric transport and deposition of chemical components (Petit et al 1999). In this regard, Mayewski et al (2005) have shown that concentrations of ionic species in the snow of 520 sites across Antarctic region vary up to four orders of magnitude and exhibit distinct geographical patterns. While ice core chemistry analyses have enhanced our knowledge on the working of the climate system and its variability through time (Legrand and Mayewski 1997; Mayewski and White 2002), an improved understanding of the fundamental factors that ultimately control the chemistry of snow or ice sample will allow even more detailed and accurate interpretation of glaciochemical records. When snow melts, water runsoff through stream channel on the barren land, rich in calcareous soil and gets collected in the

Keywords. Snow chemistry; aerosol; marine phytoplankton; sea salt. 
nearby lakes. Thus, the run-off water dissolves in it the soluble material lying in the path. As the existing lakes and pools are of paramount importance from a physical, chemical, and biological point of view, understanding chemical composition of the lake water and its quality is pertinent. A number of studies regarding snow and lake water chemistry over various regions of the continent of Antarctica have been carried out by a number of scientists (Gjessing 1984; Isaksson 1994; Stenberg et al 1998; Isaksson et al 2001; Siegert et al 2001; Bertler et al 2005; Eija et al 2005), but this kind of study over the region considered in the present study is meagre. Nijampurkar (1988), Ghosh et al (1997) and Kashyap et al (2000) have presented concentration of only partial chemical constituents and $\mathrm{pH}$ value of a few samples of either snow or lake water over very limited region around Maitri Station. In the present study, we have analyzed major ionic contents of surface snow and lake water samples spread over much larger area around the Indian Antarctic Research Station, Maitri, to understand their chemical composition and the sources of the observed chemical species. This study will also add to our knowledge of air quality over the sampled region of Antarctica.

\section{Locations of sample collection, measurement and analysis}

The Indian permanent research station 'Maitri' in the Antarctica Continent is situated on the hills of Dronning Maud Land of the Schirmacher Oasis range in the east of the continent (figures 1 and 2).

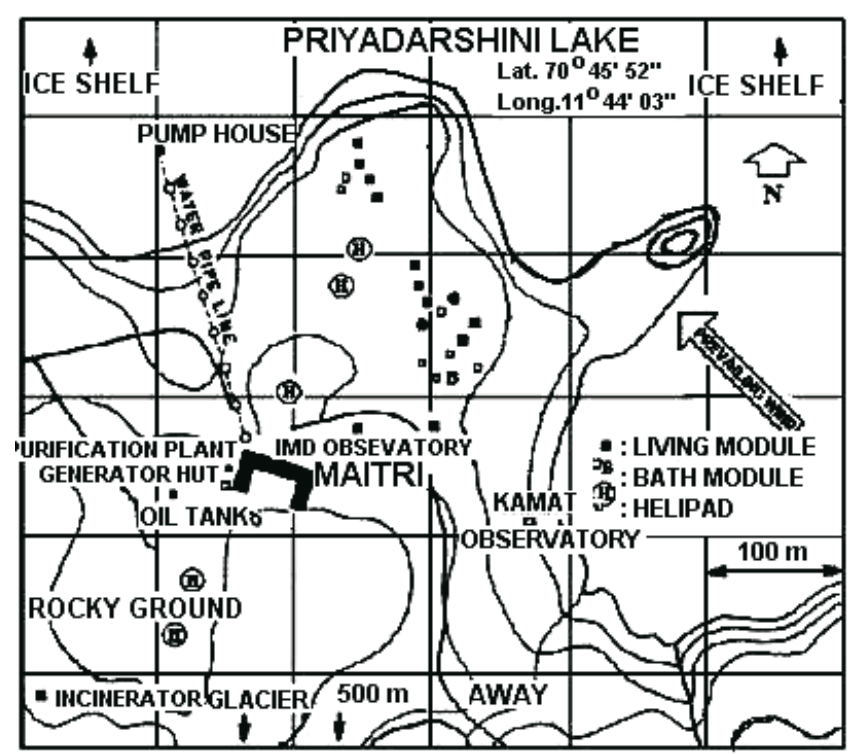

Figure 1. Detailed map of the Indian station 'Maitri' at Antarctica.
Average elevation of the area around Maitri is $117 \mathrm{~m}$ amsl, and the area is a small ice-free polar rocky hill with a maximum width of $2 \mathrm{~km}$ and length of about $18 \mathrm{~km}$ in the east-west direction. The snow-covered area during the summer season is found at a distance of more than $0.5 \mathrm{~km}$ from the station. The ground surface around the station mainly consists of loamy sand types of soil. The Indian station (Maitri), being located at the edge of the Antarctica Continent, experiences winds intermittently from both the ocean and the land. This altering airmass has an important effect on the aerosol and water vapour content over the location.

Snow and lake water samples were collected from different locations around Indian station 'Maitri', Antarctica, during 24th and 26th Indian Antarctica Expeditions (IAE) (i.e., from December 2004-March 2005 and from December 2006-March 2007, respectively). During 24th Expedition, mainly surface layer snow samples were collected mostly from the regions of Hoffman mountain range and the Russian Air base which are nearly $100 \mathrm{~km}$ away from the 'Maitri'. Helicopter was used to visit these locations for collecting the snow samples. Some snow samples were collected at locations about $0.5 \mathrm{~km}$ away from the Maitri. It may be noted that the sample numbers (S-1, S-2, etc.) shown in table $1 \mathrm{~A}$ represent the sequence of the sample collection. Two samples of blue ice (i.e., from a depth of about 1.5 feet) and one sample of lake water (Priyadarshini Lake; $70^{\circ} 45^{\prime} \mathrm{S}, 11^{\circ} 45^{\prime} \mathrm{E}$ ) were also collected during the expedition. Samples of blue ice were collected at the locations $70^{\circ} 51^{\prime} \mathrm{S}$, $11^{\circ} 30^{\prime} \mathrm{E}$ and $69^{\circ} 44^{\prime} \mathrm{S}, 13^{\circ} 24^{\prime} \mathrm{E}$. It has not been possible to prepare a map which may include all these sampling locations.

During 26th Antarctic Expedition, lake water samples were collected from different lakes around the Maitri station. Three types of lakes [Landlocked Lake (L), Pro-glacial Lake (P) and Epi-shelf Lake (E)] were selected for the sampling. Locations at which samples were collected during 20062007 are given in table $1 \mathrm{~B}$ and also in figure 2 . The numbers shown with the lake water samples are associated with the lake numbers which have been permanently assigned to the lakes by the Geological Survey of India (Ravindra 2001).

For the collection of snow sample, hand gloves and ice core machine were used to minimize manual contamination. These samples were collected in $100 \mathrm{ml}$ polythene bottles rinsed three times with triple distilled water before collection. Similarly, lake water samples were collected in $100 \mathrm{ml}$ polythene bottle with proper precautionary measure. The $\mathrm{pH}$ and conductivities of the samples were measured immediately after the collection of samples with the help of portable digital $\mathrm{pH}$ 


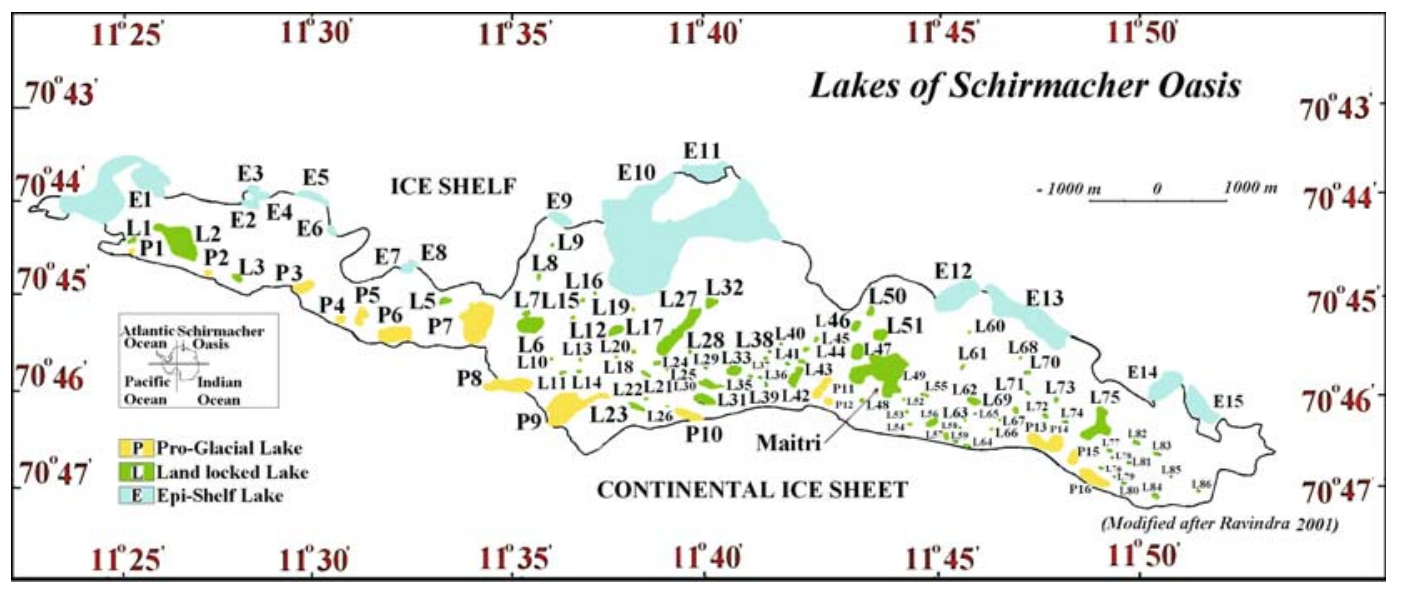

Figure 2. Sampling locations at Antarctica during 26th Antarctic Expedition (the numbers shown with the lake water samples are associated with the lake numbers which have been permanently assigned to the lakes by the Geological Survey of India).

Table 1. Snow and lake water sampling locations around Maitri (Indian station at Antarctica) during 24th and 26th Indian Antarctica Expeditions (IAE).

\begin{tabular}{|c|c|c|c|c|c|}
\hline Sl. no. & Latitude (deg) & Longitude (deg) & Sl. no. & Latitude (deg) & Longitude (deg) \\
\hline \multicolumn{6}{|c|}{ A: Snow and lake water sampling locations during 24th Expedition (December 2004-March 2005) } \\
\hline $1(\mathrm{~S}-1)$ & $72^{\circ} 07^{\prime} 28.4^{\prime \prime}$ & $04^{\circ} 26^{\prime} 04.4^{\prime \prime}$ & $10(\mathrm{~S}-11)$ & $71^{\circ} 00^{\prime} 57.4^{\prime \prime}$ & $04^{\circ} 49^{\prime} 00.0^{\prime \prime}$ \\
\hline $2(\mathrm{~S}-3)$ & $72^{\circ} 05^{\prime} 32.0^{\prime \prime}$ & $04^{\circ} 39^{\prime} 54.0^{\prime \prime}$ & $11(\mathrm{~S}-12)$ & $72^{\circ} 06^{\prime} 00.0^{\prime \prime}$ & $05^{\circ} 00^{\prime} 00.0^{\prime \prime}$ \\
\hline $3(\mathrm{~S}-4)$ & $72^{\circ} 03^{\prime} 49.0^{\prime \prime}$ & $04^{\circ} 41^{\prime} 46.0^{\prime \prime}$ & $12(\mathrm{~S}-13)$ & $72^{\circ} 00^{\prime} 44.0^{\prime \prime}$ & $04^{\circ} 29^{\prime} 00.0^{\prime \prime}$ \\
\hline $4(\mathrm{~S}-5)$ & $72^{\circ} 02^{\prime} 13.0^{\prime \prime}$ & $04^{\circ} 42^{\prime} 44.0^{\prime \prime}$ & $13(\mathrm{~S}-14)$ & $72^{\circ} 02^{\prime} 15.0^{\prime \prime}$ & $04^{\circ} 57^{\prime} 10.0^{\prime \prime}$ \\
\hline $5(\mathrm{~S}-6)$ & $71^{\circ} 59^{\prime} 16.6^{\prime \prime}$ & $04^{\circ} 33^{\prime} 57.5^{\prime \prime}$ & $14(\mathrm{~L}-17)$ & $70^{\circ} 45^{\prime} 00.0^{\prime \prime}$ & $11^{\circ} 45^{\prime} 00.0^{\prime \prime}$ \\
\hline $6(\mathrm{~S}-7)$ & $72^{\circ} 01^{\prime} 77.9^{\prime \prime}$ & $04^{\circ} 34^{\prime} 95.0^{\prime \prime}$ & $15(\mathrm{~L}-19)$ & $70^{\circ} 51^{\prime} 00.0^{\prime \prime}$ & $11^{\circ} 30^{\prime} 00.0^{\prime \prime}$ \\
\hline $7(\mathrm{~S}-8)$ & $71^{\circ} 58^{\prime} 00.9^{\prime \prime}$ & $04^{\circ} 31^{\prime} 23.4^{\prime \prime}$ & $16(\mathrm{~L}-20)$ & $69^{\circ} 44^{\prime} 00.0^{\prime \prime}$ & $13^{\circ} 24^{\prime} 00.0^{\prime \prime}$ \\
\hline 8(S-9) & $72^{\circ} 03^{\prime} 69.4^{\prime \prime}$ & $04^{\circ} 32^{\prime} 32.4^{\prime \prime}$ & $17(\mathrm{~L}-23)$ & $70^{\circ} 49^{\prime} 00.0^{\prime \prime}$ & $11^{\circ} 52^{\prime} 00.0^{\prime \prime}$ \\
\hline $9(\mathrm{~S}-10)$ & $72^{\circ} 01^{\prime} 24.1^{\prime \prime}$ & $04^{\circ} 30^{\prime} 73.3^{\prime \prime}$ & & & \\
\hline \multicolumn{6}{|c|}{ B: Lake water sampling locations during 26th Expedition (December 2006-March 2007) } \\
\hline $1(\mathrm{E}-1)$ & $70^{\circ} 44^{\prime} 20.9^{\prime \prime}$ & $11^{\circ} 24^{\prime} 30.9^{\prime \prime}$ & $17(\mathrm{~L}-67)$ & $70^{\circ} 46^{\prime} 26.9^{\prime \prime}$ & $11^{\circ} 44^{\prime} 22.9^{\prime \prime}$ \\
\hline $2(1-1)$ & $70^{\circ} 44^{\prime} 25.4^{\prime \prime}$ & $11^{\circ} 25^{\prime} 02.2^{\prime \prime}$ & $18(1-72)$ & $70^{\circ} 46^{\prime} 31.2^{\prime \prime}$ & $11^{\circ} 45^{\prime} 41.3^{\prime \prime}$ \\
\hline $3(1-2)$ & $70^{\circ} 44^{\prime} 35.8^{\prime \prime}$ & $11^{\circ} 26^{\prime} 41.7^{\prime \prime}$ & $19(1-62)$ & $70^{\circ} 46^{\prime} 19.2^{\prime \prime}$ & $11^{\circ} 44^{\prime} 22.9^{\prime \prime}$ \\
\hline $4(1-3)$ & $70^{\circ} 44^{\prime} 50.2^{\prime \prime}$ & $11^{\circ} 27^{\prime} 46.3^{\prime \prime}$ & $20(1-60)$ & $70^{\circ} 45^{\prime} 58.2^{\prime \prime}$ & $11^{\circ} 45^{\prime} 04.5^{\prime \prime}$ \\
\hline $5(\mathrm{p}-3)$ & $70^{\circ} 45^{\prime} 04.1^{\prime \prime}$ & $11^{\circ} 29^{\prime} 30.4^{\prime \prime}$ & 21(L-68) & $70^{\circ} 45^{\prime} 57.6^{\prime \prime}$ & $11^{\circ} 46^{\prime} 26.3^{\prime \prime}$ \\
\hline $6(\mathrm{p}-4)$ & $70^{\circ} 45^{\prime} 24.6^{\prime \prime}$ & $11^{\circ} 30^{\prime} 18.4^{\prime \prime}$ & $22(\mathrm{~L}-61)$ & $70^{\circ} 46^{\prime} 01.9^{\prime \prime}$ & $11^{\circ} 44^{\prime} 57.8^{\prime \prime}$ \\
\hline $7(\mathrm{~L}-6)$ & $70^{\circ} 45^{\prime} 31.9^{\prime \prime}$ & $11^{\circ} 35^{\prime} 31.4^{\prime \prime}$ & $23(1-42)$ & $70^{\circ} 46^{\prime} 10.7^{\prime \prime}$ & $11^{\circ} 40^{\prime} 57.4^{\prime \prime}$ \\
\hline $8(\mathrm{~L}-12)$ & $70^{\circ} 45^{\prime} 18.8^{\prime \prime}$ & $11^{\circ} 36^{\prime} 29.8^{\prime \prime}$ & $24(1-43)$ & $70^{\circ} 46^{\prime} 06.5^{\prime \prime}$ & $11^{\circ} 41^{\prime} 20.7^{\prime \prime}$ \\
\hline $9(\mathrm{~L}-16)$ & $70^{\circ} 45^{\prime} 16.7^{\prime \prime}$ & $11^{\circ} 36^{\prime} 21.8^{\prime \prime}$ & $25(1-44)$ & $70^{\circ} 46^{\prime} 10.4^{\prime \prime}$ & $11^{\circ} 41^{\prime} 40.2^{\prime \prime}$ \\
\hline 10(L-17) & $70^{\circ} 45^{\prime} 36.7^{\prime \prime}$ & $11^{\circ} 36^{\prime} 57.7^{\prime \prime}$ & $26(1-45)$ & $70^{\circ} 46^{\prime} 05.4^{\prime \prime}$ & $11^{\circ} 42^{\prime} 01.9^{\prime \prime}$ \\
\hline 11(L-27) & $70^{\circ} 45^{\prime} 45.1^{\prime \prime}$ & $11^{\circ} 37^{\prime} 47.7^{\prime \prime}$ & $27(\mathrm{~L}-48)$ & $70^{\circ} 46^{\prime} 18.9^{\prime \prime}$ & $11^{\circ} 43^{\prime} 06.6^{\prime \prime}$ \\
\hline $12(\mathrm{~L}-24)$ & $70^{\circ} 45^{\prime} 49.8^{\prime \prime}$ & $11^{\circ} 39^{\prime} 55.8^{\prime \prime}$ & $28(\mathrm{p}-13)$ & $70^{\circ} 46^{\prime} 32.6^{\prime \prime}$ & $11^{\circ} 44^{\prime} 38.0^{\prime \prime}$ \\
\hline $13(1-47)$ & $70^{\circ} 45^{\prime} 52.9^{\prime \prime}$ & $11^{\circ} 42^{\prime} 30.8^{\prime \prime}$ & $29(\mathrm{p}-14)$ & $70^{\circ} 46^{\prime} 43.3^{\prime \prime}$ & $11^{\circ} 45^{\prime} 28.7^{\prime \prime}$ \\
\hline $14(\mathrm{~L}-46)$ & $70^{\circ} 45^{\prime} 38.8^{\prime \prime}$ & $11^{\circ} 42^{\prime} 50.1^{\prime \prime}$ & $30(\mathrm{E}-12)$ & $70^{\circ} 45^{\prime} 28.7^{\prime \prime}$ & $11^{\circ} 45^{\prime} 11.5^{\prime \prime}$ \\
\hline $15(1-50)$ & $70^{\circ} 45^{\prime} 35.4^{\prime \prime}$ & $11^{\circ} 43^{\prime} 02.7^{\prime \prime}$ & $31(\mathrm{E}-13)$ & $70^{\circ} 45^{\prime} 31.3^{\prime \prime}$ & $11^{\circ} 46^{\prime} 25.9^{\prime \prime}$ \\
\hline $16(1-51)$ & $70^{\circ} 45^{\prime} 43.4^{\prime \prime}$ & $11^{\circ} 43^{\prime} 11.9^{\prime \prime}$ & & & \\
\hline
\end{tabular}

Note: S: Snow sample (The number with 'S' denotes serial number of the sample collection).

L: Land-locked Lake; P: Pro-glacial Lake; and E: Epi-shelf Lake. Small letter of sample identification indicates the samples showing lower ionic content and capital letter for higher ionic content. The numbers shown with the lake water samples are associated with the lake numbers which have been permanently assigned to the lakes by the Geological Survey of India. 
and conductivity meters. Chemical analyses of the samples were performed at the IITM, Pune. Every possible care was taken to avoid contamination of the collected samples. Samples were then analyzed for major chemical ions. Cations like $\mathrm{Na}^{+}, \mathrm{K}^{+}, \mathrm{Ca}^{2+}$ and $\mathrm{Mg}^{2+}$ were measured with the help of Atomic Absorption Spectrometer (Perkin Elmer, Model 400), whereas anions like $\mathrm{F}^{-}, \mathrm{Cl}^{-}, \mathrm{SO}_{4}^{2-}$ and $\mathrm{NO}_{3}^{-}$were measured by ion chromatography (DIONEX 100 USA) using analytical columns Ion Pac-AS4A-SC $4 \mathrm{~mm}$, anion micro-membrane suppressor ASRS- $1,1.8 \mathrm{mM}$ sodium carbonate $/ 1.7 \mathrm{mM}$ sodium bicarbonate as eluent and triple distilled water as regenerant. Ammonium ion was measured with the help of Spectronic 20D (Milton Roy Company 20D, USA).

Meteorological observations were also made at Maitri during both the expeditions with the help of an automatic weather station. Daily mean air temperature at Maitri during the 24th IAE was $-0.75^{\circ} \mathrm{C}$ with variation in the range from $1.41^{\circ} \mathrm{C}$ to $-8.20^{\circ} \mathrm{C}$. The corresponding mean during the 26 th IAE was $0.07^{\circ} \mathrm{C}$ with variation in the range from $4.50^{\circ}$ to $-4.80^{\circ} \mathrm{C}$. Both surface temperature and relative humidity showed a general decreasing trend from beginning to the ending time of the two Antarctic observational campaigns indicating gradual change of atmospheric conditions from summer to winter. The average surface-level wind speed was recorded to be $3.86 \mathrm{~m} / \mathrm{s}$ with a high value of $10.08 \mathrm{~m} / \mathrm{s}$, mostly from the southeasterly direction. The cloud cover over the station occurred mainly under the influence of a sub-polar lowpressure system, otherwise the sky remained clear. Detailed description on the meteorological features during both the expeditions may be seen in Sonbawne et al (2009).

\section{Data and quality check}

In order to ascertain quality of the data to be used in this study, ion balance technique (Ali et al 2004) is adopted first and is found that the sum of cations nearly balances with the sum of anions for individual samples. Ratio between the measured cations and the measured anions for snow samples varies between 1.03 and 2.07 with an average value of 1.39 and for lake water samples between 0.81 and 1.02 with an average value of 0.96 . The deviation from the ideal value of unity may be due to noninclusion of weak organic acids in some cases and of heavy metals in the other cases which have not been measured and also due to unavoidable manual error caused by manual work involved in different stages of the analyses of these samples. Further, the data for individual ions compiled separately for snow and lake water are passed the Gaussian Filter considering inclusion of all the concentration data falling within $\pm 3 \sigma$ (i.e., three times the standard deviation) of the individual series of concentration data. Finally, the quality of the data is ensured by comparison of theoretically computed conductivity (EMEP 1996) of the sample with its measured conductivity.

Figure 3 shows comparison between the two conductivities for the two kinds of samples. It can be seen that both the conductivities compare well with each other. Correlation coefficient between the two conductivities comes as 0.826 for snow samples and 0.978 for lake water samples and both the results are significant at better than $0.01 \%$. Thus, it can be said that the data selected in the present study is quality-wise well up to the mark. At the same time it is added that those data which did not comply with the quality control were discarded.

As stated earlier, the samples collected during 2004-2005 include mainly freshly deposited snow samples, one lake water sample and two blue ice samples. So, the data pertaining to their chemical species need to be grouped on the basis of the nature of the samples. On account of the fact that the major chemical ions measured in the individual categories of the samples show very much concurrency in the variation of their average

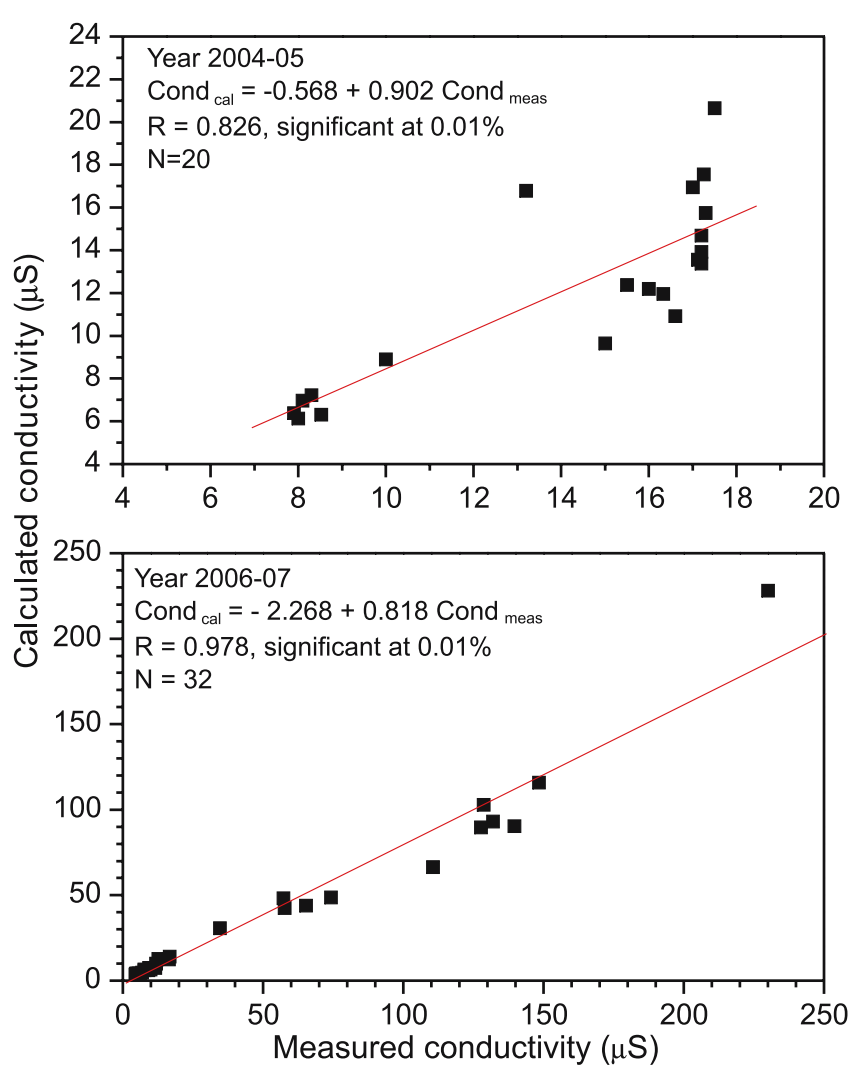

Figure 3. Measured and theoretically calculated electrical conductivity of snow and lake water samples collected at Antarctica during 24th and 26th Antarctic Expeditions. 


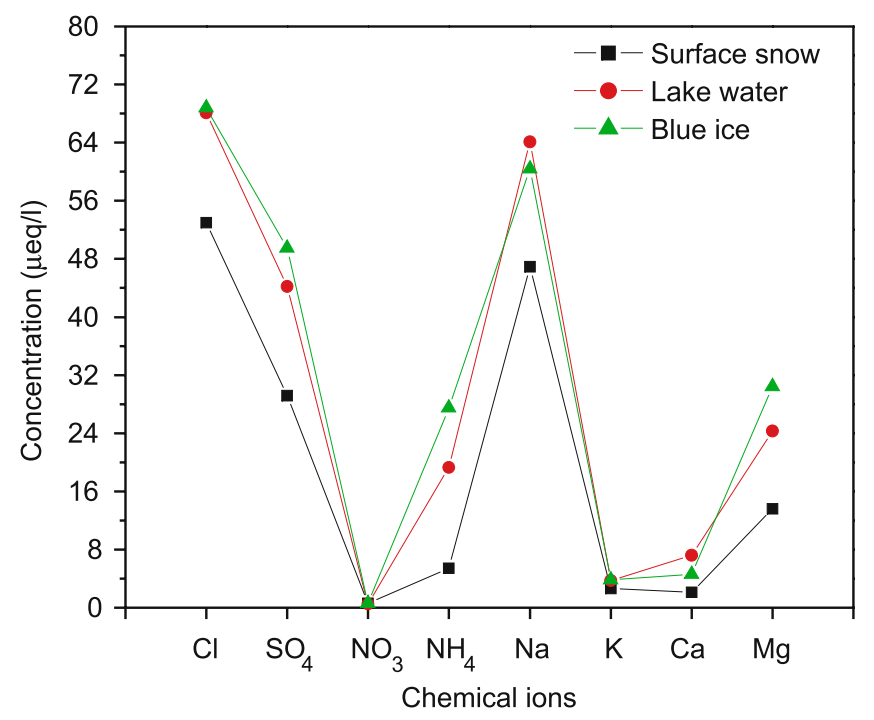

Figure 4. Concentration of different chemical species measured in surface snow, lake water and blue ice samples collected during 24th Antarctic Expedition.

concentration from $\mathrm{Cl}^{-}$to $\mathrm{Mg}^{2+}$ (figure 4), the data relating to snow, lake water and blue ice samples may be safely assumed to be drawn from the same population. That is, the sources of the chemical ions present in all the three categories of the samples may be same and there is no need of segregating data on the basis of the nature of the samples collected during 2004-2005. As such, the chemical composition of the samples collected during 2004-2005 will nearly represent chemical composition of the lower tropospheric aerosols over the Antarctic region scavenged through snow fall.

Lake water samples collected during 2006-2007 are categorized in to two groups depending on whether the samples have low or high concentration of chemical ions. Here, the criteria used to decide low or high concentration is based on the cumulative frequency plot of the sum of the concentration of all measured ions present in the individual samples (figure 5). It is seen in the plot that the slope of the graph changes at the concentration value of $250 \mu \mathrm{eq} / \mathrm{l}$. Accordingly, if the sum of the concentration of total measured ions in the individual samples is $\leq 250 \mu \mathrm{eq} / \mathrm{l}$, the sample is assumed to possess low concentration, otherwise the sample is assumed to possess high concentration. This implies that possibly two different source mechanisms may be required to explain the result of chemical composition of lake water samples collected during 2006-2007. Hereafter, the samples containing low content of ionic species will be referred to as sample 1 and the samples containing high content of ionic species will be referred to as sample 2. In all, samples possessing low concentration are 20 in number and are shown

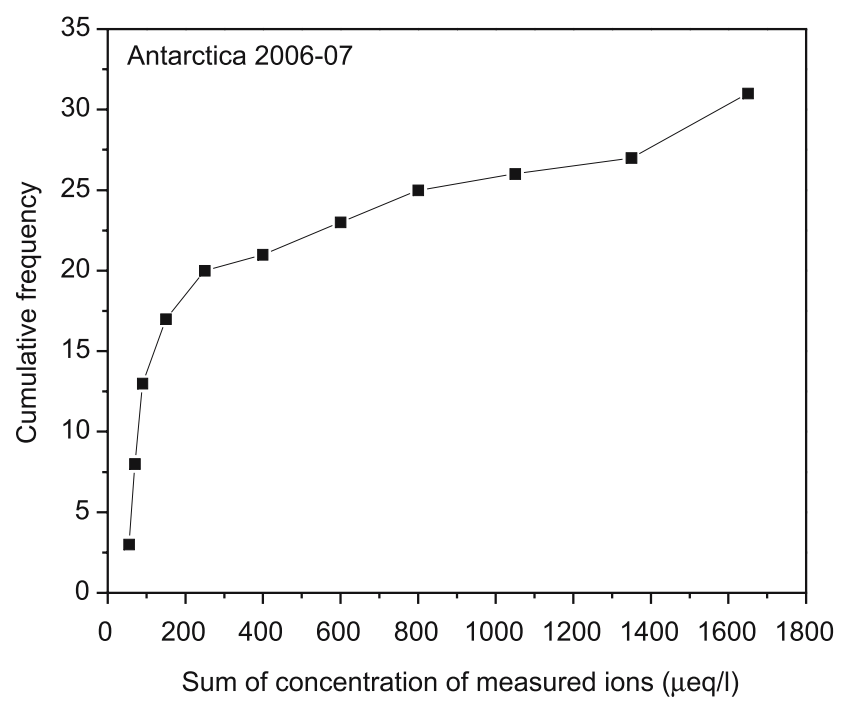

Figure 5. Cumulative frequency distribution of concentration total of the measured ions in lake water samples collected in Antarctica during Antarctic summer of 2006-2007.

in table 1B with lowercase letter. The samples which possess high concentration are 11 in number and are shown in the table with uppercase letter. Among the samples showing low concentration total there were only three samples which showed more than $200 \mu \mathrm{eq} / 1$. Among the samples showing high concentration total, there was only one sample which showed concentration total lower than $500 \mu \mathrm{eq} / \mathrm{l}$. All other samples showed concentration total more than $500 \mu \mathrm{eq} / \mathrm{l}$. Six samples showed even more than $1000 \mu \mathrm{eq} / \mathrm{l}$.

\section{Results and discussion}

\subsection{The $p H$ values of snow and lake water}

Figure 6 presents average $\mathrm{pH}$ value and chemical composition of surface ice and lake water samples collected at different locations in Antarctica during southern hemispheric summer of 2004-2005 and 2006-2007, respectively. It may be seen in the figure that the snow and the lake water samples are all slightly acidic in nature in comparison to pure water neutrality. Average $\mathrm{pH}$ value for snow samples was 6.1 and it varied between 5.7 and 6.8. Average $\mathrm{pH}$ value for lake water samples containing low content of chemicals was 6.2 with variation between 5.8 and 6.8 , whereas average $\mathrm{pH}$ value for lake water samples containing high content of chemicals was 6.5 with variation between 5.9 and 7.6. Snow samples may be acidic due to high concentration of sulfate in the Antarctic snow, which come from the oxidation of DMS, and also due to dissolution of atmospheric $\mathrm{CO}_{2}$ in that. However, some of the lake water samples may be 

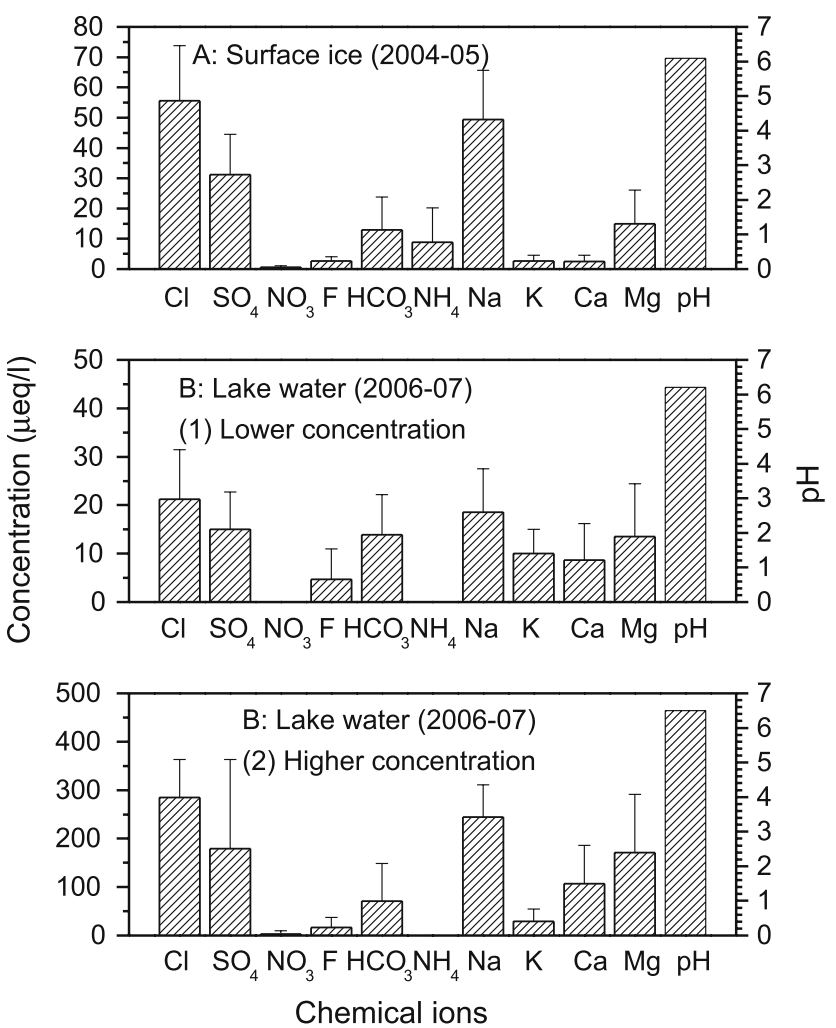

Figure 6. Average chemical composition of surface snow and lake water samples collected at different locations in Antarctica during southern summers of the years 2004-2005 and 2006-2007.

acidic because of the absence of sufficient mineral neutralizers.

Comparison of the $\mathrm{pH}$ values obtained in the present samples with those obtained for the samples collected during 13th Antarctic Expedition in 1997 (table 2) reveals that there has been no change in the $\mathrm{pH}$ value of the lake waters with the passage of nearly a decade time. Comparatively low $\mathrm{pH}$ measured in the past in the two proglacial lake waters is due to precipitated water with low conductivity, turbidity and dissolved solids, whereas more $\mathrm{pH}$ of Priyadarshini and Control Lake waters indicates the dissolution of minerals through inlet run-off waters (Ghosh et al 1997).

\subsection{Concentration of ionic species in snow and lake water}

Chemical composition of surface ice (figure 6A) reveals that concentration of $\mathrm{Na}^{+}$is maximum $(\sim 49 \mu \mathrm{eq} / \mathrm{l})$ among the cations followed by $\mathrm{Mg}^{2+}$ $(\sim 15 \mu \mathrm{eq} / \mathrm{l})$. Range of their variations is $\sim 22$ $72 \mu \mathrm{eq} / \mathrm{l}$ and $\sim 4-45 \mu \mathrm{eq} / \mathrm{l}$, respectively. Concentrations of $\mathrm{Ca}^{2+}$ and $\mathrm{K}^{+}$are very small and nearly equal. Among the measured anions, $\mathrm{Cl}^{-}$is dominant with concentration level nearly equal to $56 \mu \mathrm{eq} / \mathrm{l}$ and it varies between $\sim 25$ and $82 \mu \mathrm{eq} / \mathrm{l}$.
Considerable amount of $\mathrm{SO}_{4}^{2-}(\sim 31 \mu \mathrm{eq} / \mathrm{l})$ is also found in the samples with variation between $\sim 10$ and $65 \mu \mathrm{eq} / \mathrm{l}$. Concentration of other measured chemical ions is very small. Sodium and chloride ions, being major sea components, show high concentration because the sampling locations lie near the coastal area. The source of appreciable concentration of sulphate may be DMS mainly produced by phytoplankton which is further oxidized finally to sulphate particles.

Dominant chemical ions in the lake water sample 1 (figure $6 \mathrm{~B}$ ) are $\mathrm{Cl}^{-}$and $\mathrm{Na}^{+}$with average concentration levels equal to 21 and $18 \mu \mathrm{eq} / \mathrm{l}$, respectively. Concentration of $\mathrm{SO}_{4}^{2-}, \mathrm{Mg}^{2+}, \mathrm{K}^{+}$and $\mathrm{Ca}^{2+}$ are $\sim 15,14,10$ and $\sim 9 \mu \mathrm{eq} / 1$, respectively. Dominant ions in the lake water sample 2 also are $\mathrm{Cl}^{-}(284 \mu \mathrm{eq} / \mathrm{l})$ and $\mathrm{Na}^{+}(244 \mu \mathrm{eq} / \mathrm{l})$ followed by $\mathrm{SO}_{4}^{2-}(180 \mu \mathrm{eq} / \mathrm{l}), \mathrm{Mg}^{2+}(171 \mu \mathrm{eq} / \mathrm{l})$ and $\mathrm{Ca}^{2+}$ $(107 \mu \mathrm{eq} / \mathrm{l})$. Ratio of the average concentration of major individual ions $\left(\mathrm{Cl}^{-}, \mathrm{SO}_{4}^{2-}, \mathrm{Na}^{+}, \mathrm{Ca}^{2+}\right.$ and $\mathrm{Mg}^{2+}$ ) of sample 2 to the average concentration of corresponding ions of sample 1 lies between 12 and 13. Thus it can be inferred that chemical composition of the samples from both the groups is nearly same. Low $\mathrm{pH}$ values and low chemical content in the lake water sample 1 may be mainly due to the collection of these samples either from glacial lakes or from small lakes, whereas comparatively high $\mathrm{pH}$ and high chemical content in the other lake water samples may be due to the collection of these samples from lakes being fed from inlet run-off water and dissolving ample mineral dust in them. Another important feature seen in the ratio values are 140 times increase in $\mathrm{NO}_{3}^{-}$and only three times increase in $\mathrm{K}^{+}$ions. Although the average concentration level of $\mathrm{NO}_{3}^{-}$is small $(3 \mu \mathrm{eq} / \mathrm{l})$ in sample 2 , but such increase implies that there might have been some specific anthropogenic activity during the period of the collection of sample 2 in the vicinity of the sampling location. It is expected that their increased concentrations may be due to burning of waste matter like human excretion, wood, waste paper and waste food, etc. Three times increase in the concentration of $\mathrm{K}^{+}(29 \mu \mathrm{eq} / \mathrm{l})$ is also attributed to the same.

\subsection{Neutralization factor}

Measured abundances of cations and anions in a sample make it possible to evaluate the effectiveness of the alkaline cations in neutralizing the acidity produced by the anions in the sample. The neutralization potential of an alkaline cation is judged by the magnitude of its neutralization factor (NF) which is given by the ratio of the concentration of that cation to the sum of the 
Table 2. $p H$ value and concentration of chemical ions measured in snow, ice and lake water samples around Indian Antarctic Station during different IAE.

\begin{tabular}{|c|c|c|c|c|c|c|c|c|}
\hline \multirow[b]{2}{*}{ Nature of sample } & \multicolumn{8}{|c|}{ Major ion concentration $(\mu \mathrm{eq} / \mathrm{l})$} \\
\hline & $\mathrm{Na}^{+}$ & $\mathrm{K}^{+}$ & $\mathrm{Ca}^{2+}$ & $\mathrm{Mg}^{2+}$ & $\mathrm{Cl}^{-}$ & $\mathrm{SO}_{4}^{2-}$ & $\mathrm{NO}_{3}^{-}$ & $\mathrm{pH}$ \\
\hline \multicolumn{9}{|c|}{ A. Dakshin Gangotri (D.G.; $\left.70^{\circ} \mathrm{S}, 12^{\circ} \mathrm{E}\right)$ during 5th IAE 1988 (Nijampurkar 1988) } \\
\hline Fresh snow & 8.0 & 2.6 & 680 & 850 & 14.4 & & & \\
\hline Shelf ice (D.G.) & 11.3 & 1.0 & 3.8 & BDL & 20.0 & & & \\
\hline Shelf ice (Indian Bay) & 195.7 & 14.4 & 10.5 & 31.4 & 225.4 & & & \\
\hline Iceberg & 847.8 & 53.8 & 53 & 225 & 985.9 & & & \\
\hline Maitri Lake & 15.4 & 5.1 & 18.5 & 12.9 & 18.0 & & & \\
\hline \multicolumn{9}{|c|}{ B. Maitri $\left(70^{\circ} 45^{\prime} 53^{\prime \prime} \mathrm{S}, 11^{\circ} 44^{\prime} 3^{\prime \prime} \mathrm{E}\right)$ during 13 th IEA 1997 (Ghosh et al 1997) } \\
\hline Priyadarshini Lake (West) & & & & & 647.9 & 83.3 & 1.1 & 5.8 \\
\hline Priyadarshini Lake (North) & & & & & 676.1 & 20.8 & 0.2 & 5.7 \\
\hline Priyadarshini Lake (East) & & & & & 816.9 & 83.3 & 0.3 & 5.1 \\
\hline Priyadarshini Lake (South) & & & & & 647.9 & 83.3 & 1.0 & 6.0 \\
\hline Control Lake & & & & & 309.9 & 187.5 & 0.8 & 6.7 \\
\hline Glacier Lake West of Maitri & & & & & 309.9 & 187.5 & 1.3 & 4.6 \\
\hline Glacier Lake SE of Maitri & & & & & 281.7 & 166.7 & 0.8 & 4.6 \\
\hline \multicolumn{9}{|c|}{ C. Maitri $\left(70^{\circ} 45^{\prime} 53^{\prime \prime} \mathrm{S}, 11^{\circ} 44^{\prime} 3^{\prime \prime} \mathrm{E}\right)$ during 17 th IAE 2000 (Kashyap et al 2000) } \\
\hline Priyadarshini Lake & 442.0 & 32.1 & 124.2 & 73.8 & & & & \\
\hline Control Lake & 152.2 & 32.1 & 2.0 & 26.7 & & & & \\
\hline Waste disposal pond & 710.1 & 72.6 & 169 & 100.2 & & & & \\
\hline \multicolumn{9}{|c|}{ D. Maitri $\left(70^{\circ} 45^{\prime} 53^{\prime \prime} \mathrm{S}, 11^{\circ} 44^{\prime} 3^{\prime \prime} \mathrm{E}\right)$ during 24 th IAE and 26th IAE (present authors) } \\
\hline $2004-2005$ & 49.4 & 2.7 & 2.5 & 15.0 & 55.6 & 31.2 & 0.6 & 6.1 \\
\hline 2006-2007 (Low concentration) & 18.5 & 10.0 & 8.7 & 13.5 & 21.2 & 15.0 & 0.0 & 6.2 \\
\hline 2006-2007 (High concentration) & 244.1 & 29.1 & 107.1 & 170.8 & 284.4 & 179.7 & 3.1 & 6.5 \\
\hline
\end{tabular}

concentrations of the acidity producing anions. Among the measured anions in the snow and the lake waters, $\mathrm{NO}_{3}^{-}$and $\mathrm{SO}_{4}^{2-}$ are the major acid producing anions, whereas $\mathrm{Ca}^{2+}, \mathrm{NH}_{4}^{+}, \mathrm{Mg}^{2+}$ and $\mathrm{K}^{+}$ are the major acid neutralizing cations.

In order to ensure whether $\mathrm{Cl}^{-}$and $\mathrm{Na}^{+}$ obtained in both the snow and the lake waters originate purely from marine area or not, the $\mathrm{Cl}^{-} / \mathrm{Na}^{+}$ molar ratio (ion concentration taken in unit of $\mu \mathrm{eq} / \mathrm{l})$ for individual samples are calculated. The average value of the ratio for the snow samples of the year 2004-2005 comes as 1.13 and varies in the range 1.06-1.28, whereas for the lake water samples of the year 2006-2007 it comes as 1.16 and varies in the range 1.05-1.2. Comparing these values of the ratio with the standard value (1.16) given by Keene et al (1986), it is found that the assumption that both the $\mathrm{Cl}^{-}$and $\mathrm{Na}^{+}$originate from marine area is statistically significant. Thus it can be very safely assumed that the role of $\mathrm{Cl}^{-}$in acid production is negligible, because it is completely neutralized by the marine originated $\mathrm{Na}^{+}$.

A fraction of the concentrations of $\mathrm{Ca}^{2+}, \mathrm{Mg}^{2+}$ and $\mathrm{SO}_{4}^{2-}$ measured in the snow and the lake waters are also due to transportation from marine region in the form of neutral salt. These fractions do not play any role in deciding acidity/alkalinity of the snow/lake water. As such, while defining acid neutralization factor of a cation, only those ions are considered which originate over land, i.e., nonsea salt (nss) fractions of those ions like $\mathrm{nssCa}^{2+}$, $\mathrm{nssMg}^{2+}, \mathrm{nssK}^{+}$and $\mathrm{nssSO}_{4}^{2-}$. Non-sea salt fraction of an ion obtained in the snow and the lake water samples is computed using the formula given by Keene et al (1986). The formula used for calculating the magnitude of neutralization factor (Momin et al 2005) of a cation is given as:

$$
\begin{aligned}
& \mathrm{NF}(\mathrm{Ca})=\frac{[\mathrm{nssCa}]}{\left[\mathrm{NO}_{3}\right]+\left[\mathrm{nssSO}_{4}\right]}, \\
& \mathrm{NF}\left(\mathrm{NH}_{4}\right)=\frac{\left[\mathrm{NH}_{4}\right]}{\left[\mathrm{NO}_{3}\right]+\left[\mathrm{nsSO}_{4}\right]}, \\
& \mathrm{NF}(\mathrm{K})=\frac{[\mathrm{nssK}]}{\left[\mathrm{NO}_{3}\right]+\left[\mathrm{nssSO}_{4}\right]}, \\
& \mathrm{NF}(\mathrm{Mg})=\frac{\left[\mathrm{nssMg}^{2}\right]}{\left[\mathrm{NO}_{3}\right]+\left[\mathrm{nsSSO}_{4}\right]}
\end{aligned}
$$

The estimated magnitudes of the neutralization factor of different cations are plotted and shown in figure 7 . It is seen in the figure that 

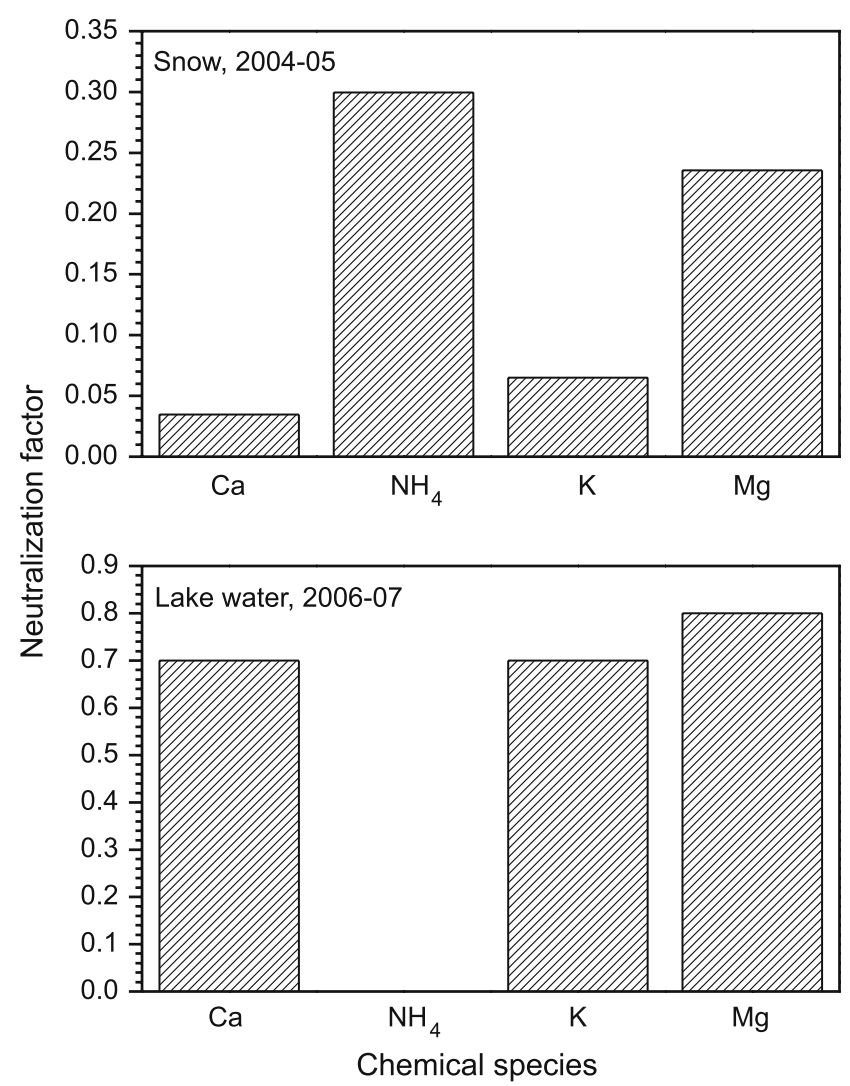

Figure 7. Neutralization factor of different cations in snow and lake water at Antarctica.

neutralization of acidic component in snow is dominated by $\mathrm{NH}_{4}^{+}$and followed by $\mathrm{Mg}^{2+}$. Neutralization by other two cations is very small. This clearly indicates dominance of anthropogenic activity over natural building up of aerosols. On the other hand, $\mathrm{Mg}^{2+}$ is the dominant neutralizer in case of lake water samples of 2006-2007. Though neutralization of acidic components by $\mathrm{Ca}^{2+}$ and $\mathrm{K}^{+}$is less, it is comparable to $\mathrm{Mg}^{2+}$. It is seen in figure 7 that the neutralization of acidic components by $\mathrm{NH}_{4}^{+}$in the lake water samples is nearly nil. This implies that the anthropogenic impact on the naturally built up chemical composition of lake water is negligible.

The Important point to be noticed here is the appearance of $\mathrm{NH}_{4}^{+}$as a dominant neutralizer in snow which may be due to the burning of waste material. The $\mathrm{NH}_{3}$ gas generated through burning reacts with acidic components present in the Antarctic atmosphere and the particles generated through this reaction is collected and trapped in the snow during snow fall. Nearly insoluble $\mathrm{NH}_{3}$ gas does not get path to enter the lake water and hence is nearly absent in the lake water.

\subsection{Factor loadings}

Source identification of different chemical ions present in snow and lake water samples collected
Table 3. Factor loadings for snow and lake water samples at Antarctica.

\begin{tabular}{llllll}
\hline & \multicolumn{2}{c}{$\begin{array}{c}\text { Samples of } \\
\text { 2004-2005 }\end{array}$} & & \multicolumn{2}{c}{$\begin{array}{c}\text { Samples of } \\
\text { 2006-2007 }\end{array}$} \\
\cline { 2 - 3 } \cline { 5 - 6 } Chemical ions & Factor 1 & Factor 2 & & Factor 1 & Factor 2 \\
\hline $\mathrm{Cl}^{-}$ & & 0.82845 & & 0.74126 \\
$\mathrm{SO}_{4}^{2-}$ & 0.76666 & & 0.91049 & \\
$\mathrm{NO}_{3}^{-}$ & & 0.82289 & & 0.78954 \\
$\mathrm{NH}_{4}^{+}$ & 0.89765 & & 0.62848 & \\
$\mathrm{Na}^{+}$ & & 0.81184 & & 0.75268 \\
$\mathrm{~K}^{+}$ & & 0.71917 & & 0.68913 & \\
$\mathrm{Ca}^{2+}$ & 0.67322 & & 0.86609 & \\
$\mathrm{Mg}^{2+}$ & 0.74263 & & & 0.79113 & \\
Eigen value & 5.81 & 1.42 & & 5.06435 & 1.57428 \\
Pct. variance & 64.5 & 15.7 & & 56.3 & 17.5 \\
Cumulative Pct. & 64.5 & 80.3 & 56.3 & 73.8 \\
\hline
\end{tabular}

at Antarctica during two southern summers was carried out through Varimax rotated factor analysis (SPSS Inc 1983) to confirm the explanation given in the earlier section about the sources. The factor loadings given in table 3 showed the data synthesized into two factors with eigen values cut off at greater than unity and explain about 74 to $80 \%$ of the total variance. A more detailed description regarding sources of different chemical species associated with different factors is given below. It is mentioned here that data are insufficient to perform factor analysis and hence only broad conclusion about the sources has been drawn.

\subsubsection{Results for snow samples}

Factor 1 registers a variance of $\sim 65 \%$ with high loadings for $\mathrm{SO}_{4}^{2-}, \mathrm{NH}_{4}^{+}, \mathrm{Ca}^{2+}$ and $\mathrm{Mg}^{2+}$. The $\mathrm{Ca}^{2+}$ and $\mathrm{Mg}^{2+}$ might have originated mostly from the soil and partly from the biomass burning. Although sources of $\mathrm{SO}_{4}^{2-}$ is the sea through oxidation of DMS generated by marine phytoplankton and sources of $\mathrm{NH}_{4}^{+}$is anthropogenic, i.e., human excretion and biomass burning, but their occurrence in the same factor implies that they might have been present in the atmosphere of Antarctica in the molecular form of $\left(\mathrm{NH}_{4}\right)_{2} \mathrm{SO}_{4}$. Factor 2 shows loadings for $\mathrm{Cl}^{-}, \mathrm{NO}_{3}^{-}, \mathrm{Na}^{+}$and $\mathrm{K}^{+}$. The $\mathrm{Na}^{+}$and $\mathrm{Cl}^{-}$may be in the form of sea salt generated from the sea but the source for the other two ionic species may be biomass and fossil fuel burning.

\subsubsection{Results for lake water samples}

Factor loadings of the measured chemical species in lake water samples are also shown in the same table. It may be seen in the table that loadings of 
$\mathrm{SO}_{4}^{2-}, \mathrm{NH}_{4}^{+}, \mathrm{K}^{+}, \mathrm{Ca}^{2+}$ and $\mathrm{Mg}^{2+}$ occur in factor 1 . The $\mathrm{K}^{+}, \mathrm{Ca}^{2+}$ and $\mathrm{Mg}^{2+}$ are originated from the soil which is dissolved in water. Source of $\mathrm{SO}_{4}^{2-}$ is DMS as mentioned earlier and of $\mathrm{NH}_{4}^{+}$is human excretion. Occurrence of both the ions in the same factor indicates that they are dissolved in the lake water as $\left(\mathrm{NH}_{4}\right)_{2} \mathrm{SO}_{4}$ particles. Factor 2 shows loadings of $\mathrm{Cl}^{-}, \mathrm{NO}_{3}^{-}$and $\mathrm{Na}^{+}$. As discussed earlier $\mathrm{Na}^{+}$and $\mathrm{Cl}^{-}$may be in the form of sea salt, whereas $\mathrm{NO}_{3}^{-}$may be due to biomass and fossil fuel burning.

\subsubsection{Comparison of the present ionic concentration with past results}

Concentration of the chemical species obtained in the present snow and lake water samples is compared with those obtained in the past corresponding samples (table 2). It is found that $\mathrm{K}^{+}$matches well with regard to its concentration, whereas the concentrations of $\mathrm{Na}^{+}$and $\mathrm{Cl}^{-}$obtained in the present samples are higher than those obtained in the past snow samples (Nijampurkar 1988). The concentrations of $\mathrm{Ca}^{2+}$ and $\mathrm{Mg}^{2+}$ in the past samples show very high concentration as compared to those obtained in the present snow samples. Past results on the concentration of other chemical ions in the snow samples are not available.

Comparison of the concentration of chemical ions present in the lake water reveals that past observed concentration of $\mathrm{Cl}^{-}$and $\mathrm{SO}_{4}^{2-}$ are very high as compared to those obtained in the present results (Ghosh et al 1997). However, the concentration of $\mathrm{NO}_{3}^{-}$is comparable and low. The concentrations of $\mathrm{Na}^{+}$and $\mathrm{Mg}^{2+}$ differ but those of $\mathrm{K}^{+}$and $\mathrm{Ca}^{2+}$ are nearly same (Kashyap et al 2000). The difference in the average concentration of some of the chemical species is understood to be due to the difference in the sampling locations, surroundings and the meteorological condition.

\section{Conclusions}

Chemistry of surface snow and lake water at Antarctica is studied on the basis of their samples collected during December 2004-March 2005 and during December 2006-March 2007, respectively. Based on this study, following broad conclusions are drawn:

- All the samples are slightly acidic. Average $\mathrm{pH}$ value for snow is 6.1. It is 6.2 for lake water with low chemical content and 6.5 for lake water with high chemical content.

- The $\mathrm{Na}^{+}$and $\mathrm{Cl}^{-}$show maximum concentrations among cations and anions respectively in both the snow and the lake water. Considerable amount of $\mathrm{SO}_{4}^{2-}$ is found in both kinds of samples which are attributed to the oxidation of DMS produced by phytoplankton.

- Dominant contributor to the total ionic mass is $\mathrm{Cl}^{-}(\sim 39 \%$ in snow and $31 \%$ in lake water $)$ followed by $\mathrm{SO}_{4}^{2-}(\sim 29 \%$ in snow and $26 \%$ in lake water $)$ and $\mathrm{Na}^{+}(\sim 22 \%$ in snow and $18 \%$ in lake water). A little higher percentage of the ions in snow may be because of trapping of the particulate matters in it.

- Neutralization of acidic component in snow is dominated by $\mathrm{NH}_{4}^{+}$and followed by $\mathrm{Mg}^{2+}$ indicating dominance of anthropogenic activity over natural building up of aerosols. The $\mathrm{Mg}^{2+}$, $\mathrm{Ca}^{2+}$ and $\mathrm{K}^{+}$are nearly equally effective in neutralizing the acidic components of lake water.

- The $\mathrm{NH}_{4}^{+}$and $\mathrm{SO}_{4}^{2-}$ occur over the Antarctica region mostly in the form of $\left(\mathrm{NH}_{4}\right)_{2} \mathrm{SO}_{4}$.

- There has not been any increase in the concentration of chemical ions in both the lake water and the snow after long time elapse.

\section{Acknowledgements}

Authors express their gratitude to Prof. B N Goswami, Director, IITM, Pune for his encouragement and support. Thanks are also due to the National Centre for Antarctic and Ocean Research (NCAOR), Goa, for funding the experiment during 24th and 26th IAE.

\section{References}

Ali K, Momin G A, Tiwari S, Safai P D, Chate D M and Rao P S P 2004 Fog and precipitation chemistry at Delhi, north India; Atmos. Environ. 38 4215-4222.

Bertler N et al 2005 Snow chemistry across Antarctica; Ann. Glaciol. 41 167-179.

EMEP 1996 Manual for sampling and chemical analysis; $E M E P / C C C$ Rep. 1/95 Norwegian.

Eija K, Kimmo T, Aki V and Minna A 2005 Spatial variations of surface snow chemistry during two austral summers in western Dronning Maud Land, Antarctica; Atmos. Environ. 39 1405-1416.

Ghosh T K, Muley R D, Ghode R and Ramteke D S 1997 Water and wastewater management at Indian Station Maitri in Antarctica; 13th Indian Expedition to Antarctica, Scientific Report, Department of Ocean Development, Technical Publication no. 2 301-311.

Gjessing Y 1984 Marine and non-marine contribution to the chemical composition of snow at the RiiserLarsenisen ice shelf in Antarctica; Atmos. Environ. 18 825-830.

Heywood R B 1984 Antarctic inland waters; In: Antarctic Ecology (ed.) Laws R M; Academic Press 1 279-344.

Isaksson E 1994 Changes in climate and atmospheric conditions between 1865-1991 inferred from a high altitude snow core, Dronning Maud Land, Antarctica; Ph.D. Thesis, Stockholm University. 
Isaksson E, Karlen W, Mayewski P I, Twickler M and Whitlow S 2001 A high-altitude snow chemistry record from Amundsenisen, Dronning Maud Land, Antarctica; J. Glaciol. 47 489-496.

Kashyap A K, Sahi A N, Shukla S P and Gupta R K 2000 Metal concentrations in water bodies of Schirmacher Oasis, Antarctica: An assessment; 17th Indian Expedition to Antarctica, Scientific Report, Department of Ocean Development, Technical Publication no. 15 211-219.

Keene W C, Pszenny A P, Galloway J N and Hawley M E 1986 Sea-salt corrections and interpretations of constituent ratios in marine precipitation; J. Geophys. Res. 91 6647-6658.

King J C and Turner W M 1997 Antarctic meteorology and climatology (Cambridge New York: Cambridge University Press) 409 pp.

Legrand M and Mayewski P A 1997 Glacio-chemistry of polar ice cores: A review; Rev. Geophys. 35 219-243.

Mayewski P A, Frezzotti M, Bertler N, Van Ommen T, Hamilton G, Jacka T H, Welch B, Frey M, Dahe Q, Jiawen R, Simoes J, Fily M, Oerter H, Nishio F, Isaksson E, Mulvaney R, Holmund P, Lipenkov $\mathrm{V}$ and Goodwin I 2005 The International Trans-Antarctic Scientific Expedition (ITASE): An overview; Ann. Glaciol. 41 180-185.

Momin G A, Ali K, Rao P S P, Safai P D, Chate D M and Praveen P S 2005 Study of chemical composition of rainwater at an urban (Pune) and a rural (Sinhagad) location in India; J. Geophys. Res. 110 D08302, doi: 10.1029/2004JD004789.

Nijampurkar V N 1988 Glaciochemical studies in Antarctica; Fifth Indian Expedition to Antarctica. Scientific Report, Department of Ocean Development, Technical Publication no. 5 219-224.
Petit J R, Jouzel J, Raynaud D, Barkov N I, Barnola J-M, Basile I, Bender M, Chappellaz J, Davis M, Delaygue G, Delmotte M, Kotlyakov V M, Legrand M, Lipenkov V Y, Lorius V, Pepin L, Ritz C, Saltzman E and Stievenard M 1999 Climate and atmospheric history of the past 420,000 years from the Vostok ice core, Antarctica; Nature 399(6735) 429-436.

Ravindra R 2001 Geomorphology of Schirmacher Oasis Pist Antarctic; In: Proc. Symp. on snow ice and glaciers; Geol. Surv. India 56 253-262.

Siegert M J, Cynan Ellis E J, Martyn T, Christoph M, Jean-Robert P, Andrey S and John C P 2001 Physical, chemical and biological processes in Lake Vostok and other Antarctic subglacial lakes; Nature 414 603-609, doi: 10.1038/414603a.

Siingh, D, Pant V and Kamra A K 2007 Measurements of positive ions and air-earth current density at Maitri, Antarctica; J. Geophys. Res. 112 D13212, doi: 10.1029/2006JD008101.

Sonbawne S M, Raj E P, Devara P C S and Dani K K 2009 Variability in sun photometer derived summertime total column ozone over the Indian station Maitri in the Antarctic region; Int. J. Rem. Sens. 30 4331-4341.

Stenberg M, Isaksson E, Hansson M, Karlen W, Mayewski P A, Twickler M S, Whitlow S I and Gundestrup N 1998 Spatial variability of snow chemistry in western Dronning Maud Land, Antarctica; Ann. Glaciol. 27 378-384.

Wolff E W, Wagenbach D, Pasteur E C, Mulvaney Legrand R M and Hall J S 1998 Relationship between chemistry of air, fresh snow and fern cores for aerosol species in coastal Antarctica; J. Geophys. Res. 103(D9) $11,057-11,070$ 